\title{
Influence of Charcoal Broiled Meat Consumption on the Liver Functions and Non-Enzymatic Antioxidants in Human Blood
}

\author{
Yousif Abd El-Aziz Elhassaneen ${ }^{1}$, Amal Mohamed El-Badawy ${ }^{2}$ \\ ${ }^{1}$ Department of Nutrition and Food Science, Faculty of Home Economics, Minoufiya University, Shebin El-Kom, Egypt; \\ ${ }^{2}$ Department of Adult Health Care, Faculty of Nursing, Minoufiya University, Shebin El-Kom, Egypt. \\ Email: yousif12@hotmail.com
}

Received October $26^{\text {th }}, 2012$; revised December $17^{\text {th }}, 2012$; accepted December $24^{\text {th }}, 2012$

\begin{abstract}
The effect of ingesting charcoal-broiled beefburgers (CBB) on the liver functions and nonenzymatic antioxidant levels in human blood was examined in twenty-nine healthy individually males (mean age $21.65 \pm 1.32$ years, range 20.32 22.42 years), non-smokers and had no occupational exposure to PAHs, who consumed two charcoal grilled beefburger per day (mean weight $70 \mathrm{gm}$ per each) at lunch time over 28 consecutive days. The mean daily intake of PAH during the consumption period was $3431 \mathrm{ng}$ and the mean daily intake of PAH per $\mathrm{kg}$ body wt/day was $46 \mathrm{ng}$. Blood samples were collected from each subject 7, 14, 21 and 28 days before, during, and after the beefburgers consumption period. glutamic-oxaloacetic transaminase (GOT), glutamic-pyruvate transaminase (GPT) and alkaline phosphatase (ALP) were significantly higher in serum of subjects during CBB consumption period compared with those of before CBB consumption ones. All of the enzyme activities still increased upper the baseline levels, before CBB consumption period, by four week after charcoal broiled meat consumption ended. In contrary, the levels of non-enzymatic antioxidants include albumin (ALB), glutathione in serum (GSH-S) and erythrocytes (GSH-E) were significantly lower in subjects during $\mathrm{CBB}$ consumption period compared with those of before CBB consumption ones. All of the non-enzymatic antioxidant levels decreased to near baseline levels, before CBB consumption period, by four week after charcoal broiled meat consumption ended. Results suggested that non-enzymatic antioxidants defense system of serum and erythrocytes was depressed and the erythrocytes as well as liver cells were exposed to oxidant stress due to oral exposure of PAH.
\end{abstract}

Keywords: PAHs; Grilled Beefburgers; Serum; Erythrocytes; Glutathione

\section{Introduction}

Consumption of grilled red meat has been associated with an increased risk for colorectal cancer and, with less consistency, with stomach, esophagus, pancreas, breast, prostate and kidney cancers. Particular attention has been given to the formation of polycyclic aromatic hydrocarbons (PAHs) during cooking, with the highest amount of the former associated to cooking meat at high temperatures and/or fat content [1-5]. PAHs constitute a widely spread group of compounds that contain two or more benzene rings. Many of these compounds have been shown to be toxic, mutagenic and/or carcinogenic by extensive experiments in vivo and in vitro systems [6-8]. Human are exposed to PAH from various occupational, environmental, dietary and medicinal sources [9-11]. With in the general population, only certain groups are exposed to occupational and medicinal sources while the major sources of PAH exposure is smoking and diets
[12-14]. Oral intake of PAH may be substantial, as shown by the World Health Organization which stated that $99 \%$ of the oral intake of PAH contributed by food, $0.9 \%$ by inhalation and $0.1 \%-0.3 \%$ by drinking water [15]. The possible sources of PAHs contamination of foodstuffs in the modern human environment are numerous and varied. A review of the literature reveals that curing smokes, contaminated soils, polluted air and water, modes of cooking, food processing and endogenous sources have been considered [16-19]. In grilled meat, Emerole et al., [17] found that, smoked meat (shai) contained a relatively higher content of both benzo(a)anthracene and benzo(a)pyrene (PAH members) were 15.5 $\mu \mathrm{g} / \mathrm{kg}$ and $8.5 \mu \mathrm{g} / \mathrm{kg}$, respectively. While Van Maanen et al., [1] found that the mean levels of benzo(a)pyrene and pyrene in the grilled hamburgers were 8.6 and $26.5 \mu \mathrm{g} /$ $\mathrm{kg}$, respectively. All of these studies reported that the PAH levels in grilled meat were found to be strongly dependent on the method of cooking, the type of heat 
source used and the fat content of the meat. For example, the benzo(a)pyrene content in meat grilled on an open $\log$ fire was reported to be as high as $50 \mu \mathrm{g} / \mathrm{Kg}$ [11].

For these reason, many studies have been tried to establish the effect of oral exposure to PAH in humans by determination the PAH metabolites in urine [20], blood [21] and liver [8]. Others investigate the levels of PAHDNA adduct formation $[1,8,22]$. All of these studies was and still suffered from many set backs include extensive interindividual variation was observed in the amounts of biomarker measured following presumed similar exposures. Also, the detection and quantitation of PAH metabolites and the adduct formation between PAH and DNA of human is not a simple task because the analytical techniques currently available are sparse. Therefore, the present study aimed to search for more biomarkers as affected by $\mathrm{PAH}$ oral exposure through investigating the liver functions and the levels of natural biological antioxidant in human blood.

\section{Materials and Methods}

\subsection{Subjects}

The subjects of this study consisted of 29 healthy individuals who attended the outpatient clinic for medical check-up. The sample was convenient sample. Subjects were eligible for the study if they had normal liver function results, free from any medical condition, young, non smoker and have no occupational exposure to PAH. They volunteered to consume two charcoal grilled beefburgers pre day (mean weight $70 \mathrm{~g}$ per each) over 28 consecutive days. Another criterion for inclusion in this study was that they are living in the nearest area from Shebin El-Kom, having telephone at home and willing to comply with intervention or data collection procedure. They were all male and ranged age from 20.32 - 22.42 years with mean age $21.65 \pm 1.32$ years. Permission from responsible authorities to carry out the study was obtained

\subsection{Tools of the Study}

Based on review of relevant literature three tools were used. The tools included demographic questionnaire, feeding protocol and blood analysis.

\section{Tool (1): Demographic questionnaire:}

The questionnaire was used to identify the sociodemographic such as age, smoke, life style habits and medical history.

\section{Tool (2): Feeding protocol}

Feeding protocol was done for all selected subjects who met the criteria and accept to continue with the study period to investigate the effect of ingesting charcoal-broiled beefburgers on their liver functions and nonenzymatic antioxidant levels.

\section{Tool (3): Blood analysis}

Blood analysis was done to investigate liver enzymes activity and nonenzymatic antioxidants levels before, during and after intervention.

\subsection{Methods}

The data collection were done in three phases, including questionnaire and sample selection, feeding and blood drawn protocol, and analysis.

\section{Phase (1): Questionnaire and sample selection}

The authors developed a questionnaire to assess the subject eligibility to involve in the study. It contains four questions. The first two were concerned with the participant biosocial characteristics, including age, smoke, Question three was concerned with medical history and question four was concerned with their life-style habits. The authors interview with each participant and ask him to fill the questionnaire and give a blood sample for investigating the liver enzyme before the study intervention. The participants who met the criteria and accept to continue with the study period were selected. The inform consistent was obtained.

\section{Phase (2): Feeding and blood drawn protocol}

All participants were volunteered to consume two charcoal-grilled beefburgers per day (mean weight 70 g/beefburger) over 28 consecutive days. Beefburger samples were purchased from the local butchers and grilled without anything added over charcoal briquettes on an outdoor grill until well done. The participants met daily during the 28 day feeding period and ate the prepared CBB between 1:00 pm and 3:00 pm in the presence of the study investigators and their assistance's. A 5 $\mathrm{mL}$ of heparinized blood sample was drawn from each participant 12 times in the study period. It divided into three periods which included before, during and after the consumption of CBB. The first period was before the consumption of CBB by 28 days, the blood sample was drawn four times on days 7, 14, 21 and 28 to investigate the liver enzymes before the consumption of CBB and to make sure that participants were having normal liver enzymes. The second period was during consumption of CBB, the blood samples was drawn four times on days 7 , 14,21 and 28 to investigate the effect on liver enzymes. The third period was after the consumption of CBB by 28 days, the blood samples was drawn four times on days $7,14,21$ and 28 to investigate the effect on liver enzymes one month after consumption of CBB. The participants agreed to refrain from consumption of other PAH-containing food items such as charcoal broiled and smoked foods. This food items was prohibited from consumption before the actual consumption period and 4 weeks after the consumption period. The feeding and the drawing blood sample protocol were approved in ad- 
vance by the Committee on the Industrial and Public Health, Faculty of Medicine, Minoufiya University, Shebin El-Kom, Egypt.

\section{Phase (3): Analysis}

PAHs estimation in charcoal grilled beef-burgers

PAHs was extracted from food samples and purified according to the method mentioned in A.O.A.C. [23]. In brief, $100 \mathrm{gm}$ of each grind food samples was placed in 1 $\mathrm{L}$ boiling flask and $400 \mathrm{~mL}$ ethanol plus $15 \mathrm{gm}$ of $\mathrm{KOH}$ were added. Reflux condensers were inserted to the flasks and boiling then 2 hours at rapid rate. Then water added and the hydrocarbons partitioned into isooctane. Interfering materials were removed by column chromatography on Florisil, followed by selective extraction of PAH into dimethyl sulfooxide (DMSO). Further interfering materials were removed by column chromatography on Sephadex LH-20, utilizing a solvent of toluene: ethanol (1:1) to obtained the PAH purified extracts. These extracts represented the samples ready to inject in HPLC for determining the PAH members concentration. Throughout this study a SP Thermo Separation Products Liquid Chromatograph (Thermo Separation products, San Jose, CA, USA) was used with a pump Consta Metvic 4100, a Spectra Series AS100, Spectra System UV 1000 UV/Visible Spectrophoto-meter Detector, and a PC 1000 system software. A Hypersil BDS-C18, $5 \mu \mathrm{m}$ (150 $\times 4.6 \mathrm{~mm}$; Alltech, Baltimore, USA) column was used for standard and PAH samples.

PAH standards Naphthalene, NPH; fluorene, Flu; anthracene, Ant; phenanthrene, Phe; pyrene, Pyr; chrycene, Chr; benz $(a)$ anthracene, $\mathrm{B}(a) \mathrm{A}$; benz $(b)$ anthracene, $\mathrm{B}$ (b)A; benzo(a)pyrene, $\mathrm{B}(a) \mathrm{P}$; benzo(e)pyrene, $\mathrm{B}(e) \mathrm{P}$ and dibenz $(a, h)$ anthracene, $\mathrm{DB}(a, h) \mathrm{A}$ (Fluka Chemical Co., Switzerland) were dissolved in mobile phase at approximately $1 \mathrm{mg} / \mathrm{ml}$ stock solutions. Standard solutions made from the stock solutions contained approximately 0.5 to 1 $\mu \mathrm{g} / 10 \mu \mathrm{l}$ mobile phase. Retention time for PAHs standard were determined from the UV detector using isocratic elution program described in our previous study Elhassaneen and Twfik [24] as follow: mobile phase: acetonitril:water (75:25); flowrate, $1.0 \mathrm{~mL} / \mathrm{min}$; and detector, $\mathrm{UV}$ at $254 \mathrm{~nm}$.

\section{Hematological analysis}

Blood samples were drawn from the antecubital vein into glass centrifuge tubes, in which there was oxalate solution (1.34\%) as anticoagulant by authors. After centrifugation at $3000 \mathrm{rpm}$ for $10 \mathrm{~min}$., plasma was draw off and used for the analysis of blood lipid parameters and vitamins. Erythrocyte residue were washed with three successive portions of sodium chloride solution $(0.9 \%)$ and then haemolysed with deionised water for $30 \mathrm{~min}$. Haemolysate was then centrifuged at $3000 \mathrm{rpm}$ for 30 min. and the supernatant fractions was transferred to a clean test tube and for the analysis of GSH [25].

Glutathione concentrations (GSH) were determined in serum and RBC's samples by modification of the fluorometric method of Hissin and Hift [26], which is specific for reduced glutathione at $\mathrm{pH}$ 8.0. In brief, cells were collected by scraping and homogenized in handheld glass-glass homogenizer in 5\% TCA. After taking an aliquot for protein determination by lowery method [27], samples were centrifuged at $1200 \mathrm{~g}$ for $2 \mathrm{~min}$ and the GSH concentration was determined for the supernatant. Samples were incubated with $100 \mu \mathrm{L} O$-phathalaldehyde $(0.1 \%$ in methanol) and phosphate buffer $(0.1 \mathrm{M}, \mathrm{pH} 8.0$ with $5 \mathrm{mM}$ EDTA) for a final volume of $2 \mathrm{~mL}$ for $10 \mathrm{~min}$ at room temperature. Samples fluorescence was then read in a fluorometer at an excitation of $350 \mathrm{~nm}$ and emission of $420 \mathrm{~nm}$. AST, ALT and AP enzymes as well as ALB level were determined in serum samples using specific kits purchased from El-Nasr Pharmaceutical Chemicals Company, Cairo, Egypt.

\section{Statistical analysis}

Statistical analysis was performed with the Student $t$-test and MINITAB 12 computer program (Minitab Inc., State College, PA).

\section{Results}

Data of the analyses on PAH content of charcoal broiled beefburger samples used in feeding subjects are shown in Table 1. A relatively large variation in the PAH content of different samples of charcoal broiled beefburger was observed. According to our previous investigations, the differences in PAH content of beefburger samples are probably due to differences in fat content, for instance we found directly relationship between $\mathrm{PAH}$ in grilled meat and fish samples and their fat content [11]. During CBB consumption period, the mean daily intake of NPH, Flu, Ant, Phe, Pyr, Chr, B(a)A, B(b)A, B(e)P, B(a)P, $\mathrm{DB}(a, h) \mathrm{A}$ and unknown peak during the consumption period were 79.80, 58.80, 279.72, 97.44, 1534.40, 56.70, $77.00,163.10,253.96,549.64$ and $82.60 \mathrm{ng}$, respectively. The mean daily intake of these compounds per kg body wt/day were $1.07,0.79,3.75,1.31,20.57,0.76,1.03$, $2.19,3.40,7.37,1.11$ and $2.65 \mathrm{ng}$, respectively.

Mean \pm SD values of liver function enzyme activities in subjects serum were given in Table 2, and those of nonenzymatic antioxidants levels in serum and erythrocytes in Table 3. Intra correlation coefficient between liver function enzyme activities of the periods were given in Table 4, those between non-enzymatic antioxidants levels in Table 5 and those between liver function enzyme activities and nonenzymatic antioxidants levels in Table 6. Inter correlation analysis of different parameters amongst periods before, during and after CBB consumption were given in Table 7. 
Non-Enzymatic Antioxidants in Human Blood

Table 1. PAHs determined (ng/kg) in analysis of charcoal broiled beefburger samples used in feeding subjects.

\begin{tabular}{|c|c|c|c|c|c|}
\hline PAHs & Abbreviation & Molecular weight & No. of rings & Range $(\mathrm{n}=8)^{*}$ & Mean $\pm \mathrm{SD}$ \\
\hline Naphthalene & NPH & 128 & 2 & $426-698$ & $570 \pm 92$ \\
\hline Fluorene & Flu & 166 & 3 & $311-561$ & $420 \pm 88$ \\
\hline Anthracene & Ant & 178 & 3 & $1433-2621$ & $1998 \pm 454$ \\
\hline Phenanthrene & Phe & 178 & 3 & $602-996$ & $696 \pm 77$ \\
\hline Pyrene & Pyr & 202 & 4 & $4900-14954$ & $10960 \pm 3311$ \\
\hline Chrycene & $\mathrm{Chr}$ & 228 & 4 & $321-587$ & $405 \pm 61$ \\
\hline $\operatorname{Benz}(a)$ anthracene & $\mathrm{B}(a) \mathrm{A}$ & 228 & 4 & $419-691$ & $550 \pm 120$ \\
\hline $\operatorname{Benz}(b)$ anthracene & $\mathrm{B}(b) \mathrm{A}$ & 228 & 4 & $850-2440$ & $1165 \pm 290$ \\
\hline Benzo(e)pyrene & $\mathrm{B}(e) \mathrm{P}$ & 252 & 5 & $1140-3224$ & $1814 \pm 542$ \\
\hline Benzo(a)pyrene & $\mathrm{B}(a) \mathrm{P}$ & 252 & 5 & $998-4847$ & $3926 \pm 757$ \\
\hline $\operatorname{Dibenz}(a, h)$ anthracene & $\mathrm{DB}(a, h) \mathrm{A}$ & 278 & 5 & $478-689$ & $590 \pm 69$ \\
\hline Unknown & & & & $1015-1854$ & $1410 \pm 207$ \\
\hline
\end{tabular}

${ }^{*} \mathrm{n}=$ number of samples analysis.

Table 2. Mean \pm SD values of liver function enzymes activities in subjects serum before, during and after consumption of charcoal broiled beefburger $(C B B)$ for 28 days $(n=29)$.

\begin{tabular}{|c|c|c|c|c|}
\hline Period (weeks) & & $\begin{array}{l}\text { Glutamate-oxaloacetate transferase } \\
(\mathrm{GOT}, \mu \mathrm{l} / \mathrm{L})\end{array}$ & $\begin{array}{c}\text { Glutamate-pyruvate transferase } \\
(\mathrm{GPT}, \mu \mathrm{L} / \mathrm{L})\end{array}$ & $\begin{array}{c}\text { Alkaline phosphatase } \\
\text { (ALP, U/L) }\end{array}$ \\
\hline \multirow{4}{*}{$\begin{array}{l}\text { Before } \mathrm{CBB} \text { consumption } \\
\text { I }\end{array}$} & -3 & $10.77 \pm 0.85$ & $9.43 \pm 1.12$ & $147.81 \pm 12.54$ \\
\hline & -2 & $11.96 \pm 1.49$ & $8.91 \pm 1.04$ & $144.49 \pm 13.27$ \\
\hline & -1 & $12.08 \pm 1.18$ & $10.17 \pm 1.22$ & $168.59 \pm 8.84$ \\
\hline & 0 & $10.91 \pm 1.30$ & $10.58 \pm 1.44$ & $161.12 \pm 10.89$ \\
\hline \multirow[t]{2}{*}{ Mean \pm SD } & & $11.43 \pm 0.59$ & $9.77 \pm 0.65$ & $155.50 \pm 9.79$ \\
\hline & 1 & $12.48 \pm 2.13$ & $10.56 \pm 1.09$ & $171.49 \pm 14.00$ \\
\hline \multirow{3}{*}{$\begin{array}{l}\text { During CBB consumption } \\
\text { II }\end{array}$} & 2 & $13.77 \pm 2.00$ & $12.87 \pm 1.22$ & $167.39 \pm 6.39$ \\
\hline & 3 & $16.75 \pm 2.31$ & $15.05 \pm 1.01$ & $187.29 \pm 13.25$ \\
\hline & 4 & $17.10 \pm 2.11$ & $14.89 \pm 1.61$ & $193.68 \pm 12.94$ \\
\hline \multirow[t]{2}{*}{ Mean \pm SD } & & $15.03 \pm 1.96$ & $13.34 \pm 1.82$ & $179.96 \pm 10.86$ \\
\hline & 5 & $15.85 \pm 1.93$ & $14.91 \pm 1.08$ & $182.86 \pm 17.32$ \\
\hline \multirow{3}{*}{$\begin{array}{c}\text { After CBB consumption } \\
\text { III }\end{array}$} & 6 & $14.20 \pm 1.86$ & $11.16 \pm 1.28$ & $182.22 \pm 18.89$ \\
\hline & 7 & $12.05 \pm 1.75$ & $9.75 \pm 1.08$ & $172.73 \pm 10.99$ \\
\hline & 8 & $12.57 \pm 1.81$ & $11.52 \pm 1.40$ & $162.69 \pm 10.89$ \\
\hline \multirow[t]{2}{*}{ Mean \pm SD } & & $13.66 \pm 1.49$ & $11.83 \pm 1.89$ & $175.12 \pm 8.22$ \\
\hline & \multicolumn{3}{|c|}{ Statistical analysis } & \\
\hline \multicolumn{2}{|l|}{ I - II } & $\mathrm{p}<0.001$ & $\mathrm{p}<0.0001$ & $\mathrm{p}<0.0001$ \\
\hline \multicolumn{2}{|l|}{ III - II } & $*$ & $\mathrm{p}<0.001$ & * \\
\hline \multicolumn{2}{|l|}{ I - III } & $\mathrm{p}<0.001$ & $\mathrm{p}<0.001$ & $\mathrm{p}<0.001$ \\
\hline
\end{tabular}

"non significant $(\mathrm{p}>0.05)$. 
Table 3. Mean \pm SD values of nonenzymatic antioxidants levels in subjects serum and erythrocytes before, during and after consumption of charcoal broiled beefburger (CBB) for 28 days $(n=29)$.

\begin{tabular}{|c|c|c|c|c|}
\hline Period (weeks) & & $\begin{array}{l}\text { Serum albumin } \\
(\mathrm{ALB}, \mathrm{gm} / \mathrm{L})\end{array}$ & $\begin{array}{l}\text { Serum glutathione } \\
(\mathrm{GSH}-\mathrm{S}, \mu \mathrm{mol} / \mathrm{L})\end{array}$ & $\begin{array}{l}\text { Erythrocytes glutathione } \\
\text { (GSH-E, } \mathrm{mg} / 100 \mathrm{~mL} \text { ) }\end{array}$ \\
\hline \multirow{4}{*}{$\begin{array}{l}\text { Before CBB consumption } \\
\text { I }\end{array}$} & -3 & $50.10 \pm 6.41$ & $8.22 \pm 0.78$ & $75.06 \pm 5.86$ \\
\hline & -2 & $52.40 \pm 6.84$ & $7.01 \pm 0.61$ & $80.45 \pm 5.38$ \\
\hline & -1 & $48.21 \pm 4.95$ & $8.44 \pm 0.84$ & $78.80 \pm 5.06$ \\
\hline & 0 & $44.82 \pm 4.48$ & $7.67 \pm 0.67$ & $73.78 \pm 4.60$ \\
\hline \multirow{2}{*}{ Mean \pm SD } & & $48.88 \pm 2.78$ & $7.83 \pm 0.55$ & $77.02 \pm 2.71$ \\
\hline & 1 & $48.02 \pm 5.63$ & $7.06 \pm 0.71$ & $71.20 \pm 4.51$ \\
\hline \multirow{3}{*}{$\begin{array}{l}\text { During CBB consumption } \\
\text { II }\end{array}$} & 2 & $51.54 \pm 5.11$ & $6.08 \pm 0.73$ & $68.66 \pm 5.47$ \\
\hline & 3 & $47.87 \pm 3.82$ & $6.17 \pm 0.68$ & $67.20 \pm 5.27$ \\
\hline & 4 & $47.58 \pm 2.78$ & $5.05 \pm 0.84$ & $60.84 \pm 8.12$ \\
\hline \multirow[t]{2}{*}{ Mean \pm SD } & & $48.50 \pm 2.53$ & $6.09 \pm 0.71$ & $66.98 \pm 3.82$ \\
\hline & 5 & $47.73 \pm 4.43$ & $5.51 \pm 0.78$ & $63.77 \pm 5.86$ \\
\hline \multirow{3}{*}{$\begin{array}{l}\text { After CBB consumption } \\
\text { II }\end{array}$} & 6 & $46.34 \pm 3.72$ & $7.99 \pm 0.52$ & $70.75 \pm 5.15$ \\
\hline & 7 & $46.37 \pm 5.47$ & $8.14 \pm 0.71$ & $70.29 \pm 5.34$ \\
\hline & 8 & $50.49 \pm 5.63$ & $8.10 \pm 0.69$ & $75.10 \pm 6.49$ \\
\hline \multirow[t]{2}{*}{ Mean \pm SD } & & $47.68 \pm 1.95$ & $7.43 \pm 1.11$ & $69.98 \pm 4.05$ \\
\hline & & \multicolumn{2}{|c|}{ Statistical analysis } & \\
\hline \multicolumn{2}{|l|}{ I - II } & $*$ & $\mathrm{p}<0.0011$ & $\mathrm{p}<0.001$ \\
\hline \multicolumn{2}{|l|}{ III - II } & * & $\mathrm{p}<0.0011$ & $\mathrm{p}<0.0051$ \\
\hline \multicolumn{2}{|l|}{ I - III } & * & * & $\mathrm{p}<0.001$ \\
\hline
\end{tabular}

"non significant $(\mathrm{p}>0.05)$

Table 4. Intra correlation analysis between enzyme activities of the periods.

\begin{tabular}{lccc}
\hline Periods & GOT/GPT & GOT/ALP & GPT/ALP \\
\hline Before CBB consumption & n.c. & 0.265 & 0.418 \\
During CBB consumption & 0.520 & 0.440 & 0.552 \\
After CBB consumption & 0.352 & 0.351 & 0.540 \\
\hline
\end{tabular}

n.c.: no correlation $(\mathrm{p}>0.05)$.

Table 5. Intra correlation analysis between nonenzymatic antioxidants levels of the periods.

\begin{tabular}{lccc}
\hline Periods & ALB/GSH-S & ALB/GSH-E & GSH-S/GSH-E \\
\hline Before CBB consumption & 0.454 & 0.605 & 0.585 \\
During CBB consumption & 0.295 & 0.237 & 0.448 \\
After CBB consumption & 0.238 & 0.318 & 0.466 \\
\hline
\end{tabular}

n.c.: no correlation $(\mathrm{p}>0.05)$. 
Table 6. Intra correlation analysis between enzyme activities and nonenzymatic antioxidants levels of the periods.

\begin{tabular}{cccc}
\hline Parameters & Before CBB consumption & During CBB consumption & After CBB consumption \\
\hline GOT/ALB & 0.320 & -0.328 & n.c. \\
GOT/GSH-S & 0.373 & n.c. & n.c. \\
GOT/GSH-E & 0.520 & n.c. & n.c. \\
GPT/ALB & n.c. & -0.374 & n.c. \\
GPT/GSH-S & n.c. & n.c. & n.c. \\
GPT/GSH-E & 0.281 & n.c. & n.c. \\
ALP/ALB & n.c. & n.c. & n.c. \\
ALP/GSH-S & n.c. & -0.257 & n.c. \\
ALP/GSH-E & 0.308 & n.c. & n.c. \\
\hline
\end{tabular}

n.c.: no correlation $(p>0.05)$.

Table 7. Inter correlation analysis of different parameters amongst periods (before, during and after CBB consumption).

\begin{tabular}{lcccccc}
\hline Periods & GOT & GPT & ALP & ALB & GSH-S & GSH-E \\
\hline Before/during CBB consumption & 0.228 & 0.401 & 0.546 & n.c. & 0.332 & 0.464 \\
During/after CBB consumption & n.c. & -0.299 & -0.432 & n.c. & n.c. & 0.272 \\
Before/after CBB consumption & n.c. & n.c. & -0.283 & n.c. & n.c. & 0.475 \\
\hline
\end{tabular}

n.c.: no correlation $(\mathrm{p}>0.05)$.

As seen from Table 2, GOT, GPT and ALP were significantly higher in serum of subjects during CBB consumption period compared with those of before CBB consumption period. All of the enzyme activities still increased upper the baseline levels, before CBB consumption period, by four weeks after charcoal broiled meat consumption ended.

The levels of nonenzymatic antioxidants include GSH-S, GSH-E were significantly lower in subjects during $\mathrm{CBB}$ consumption period compared with those of before CBB consumption period (Table 3). All of the nonenzymatic antioxidant except ALB levels increased to near baseline levels, before CBB consumption period, by four weeks after charcoal broiled meat consumption ended.

In the intra and inter correlation analyses, some correlation's established before CBB consumption period were different from those of during and after CBB consumption periods. For example, the relations between GOT and ALB, GSH-S, GSH-E; GPT and GSH-E; ALP and GSH-E were positive in before CCB consumption period (Table 6). All of these relations were disappeared during $\mathrm{CCB}$ consumption period and new negative relations between ALB and GOT, GPT; ALP and GSH-S were appeared. Also, there is no relation at all found in period of after $\mathrm{CCB}$ consumption. Intra relations between enzyme activities exhibited also differences among the groups (Table 4). In this regard, CBB consumption caused positive relation between GOT and GPT. In the inter correlation analysis carried out between blood parameters of the subjects before and during CBB consumption, positive correlation were found for all studied parameters. But in during and after $\mathrm{CBB}$ consumption negative relations were found for GPT and ALP (Table 7).

\section{Discussion}

In the present study we observed an extensive variation in the PAH content of different samples of beefburgers used in feeding subjects. Our previous studies and others reported that the PAH levels in grilled meat are dependent on the fat content of the meat, the method of cooking and the type of heat source used. For example, the B(a)P content in charcoal-barbecued meat were ranged 1.24 $1.84 \mu \mathrm{g} / \mathrm{kg}$ in compared with $0.51-0.69 \mu \mathrm{g} / \mathrm{kg}$ meat grilled on an open log fire [11], Also, the $\mathrm{B}(a) \mathrm{P}$ content in meat grilled on an open log fire was reported to be as high as $50 \mu \mathrm{g} / \mathrm{kg}$ [28]. Van Maanen et al., [1] stated that the fat which is deposited on the charcoal broiled and the fumes will subsequently deposit PAH on the hamburgers. Another factor is the incomplete combustion of the fuel and the deposition of particles on the food [18]. 
The mean daily intake of PAH during the consumption period in the present study was $3.43 \mu \mathrm{g}$. Several previous studies have been measured or calculated exposure to PAH by food intake. In the UK, in 1979 a daily intake of $3.7 \mu \mathrm{g}$ total PAH was measured. In the Netherlands, during 1984 and 1986, mean daily intakes of 5.4 and 6.7 $\mu \mathrm{g}$ total PAH were measured, respectively [14]. The differences in the determined levels of exposure to PAH by food are still under debate. Unfortunately, there are no limits concern the allowed level of PAH in charcoal broiled beefburger mentioned in FAO/WHO Codex and the Egyptian Standard Specification. Consequently, it is difficult to evaluate the obtained general averages of PAH content in charcoal broiled beefburger under the present study.

It is well known that, the liver is the main target for toxic chemicals including polycyclic aromatic hydrocarbons (PAH) [29]. Many authors studied the mechanism of action of these compounds inside the liver cells. One of the most useful theories to explain some mechanistic aspects of PAH carcinogens is the theory of toxification, i.e. the formation of reactive metabolites by enzymes and the covalent linkage of these activated intermediates with cellular macromolecules to initiate the carcinogenic process [8]. Although the intermediate pathway of toxification for $\mathrm{PAH}$ has received wide acceptance, many other pathways and mechanisms have been suggested. For example, PAH toxification via the free-radical pathway has received much attention with long time ago. In this regard, studies from the laboratory of Ts'o are interesting; they propose that quinones of PAH owe their activity to oxidation-reduction cycles involving quinone, hydroquinone, and molecular oxygen [30]. The reactive reduced oxygen radicals and semiquinone radicals formed during these cycles have been shown to be mutagenic in bacterial as well as mammalian cells $[31,32]$. They are induce a variety of other types of genetic damage, including chromosomal aberrations and sister chromatid exchanges, DNA strand breaks and oxidative modification of DNA bases, cell transformation, and chromosomal abnormality [33]. Oxidant damage to DNA, protein, and other macromolecules appears to be a major contributing factor to aging and the many degenerative processes associated with it, including cancer, heart disease, cataracts, and cognitive dysfunction [22, 34-36].

The primary defense protecting the biological systems against the potentially harmful effect of free radicals is provided by antioxidants [37]. For examples, glutathione (GSH) is the principal sulfur reducing agent of the cell and a primary antioxidant. It helps maintain the structure of red blood cell membranes and other cellular proteins as well as maintain the cytoplasm in a reduced state [38].
Low levels of reduced GSH are associated with oxidative stress in aging, toxic exposure and AIDS. As an antioxidant, GSH assists an enzyme glutathione peroxidase that inactivates hydrogen peroxide and oxidized lipids (lipid peroxides), and prevents them from liberating damaging, highly reactive agents [39]. It can also quench free radicals directly and maintains vitamin $\mathrm{E}$ in a reduced state. GSH plays an additional, protective role in the liver, where it combines with toxic materials and their waste products including PAH permitting more efficient excretion [8]. Beside GSH, serum albumin (ALB) is represent one of the most important metal binding proteins synthesized and secreted only by the liver. Besides helping to transport a number of primarily hydrophobic compounds in the circulation, it is a sacrificial antioxidant that can bind copper tightly and iron weakly to its surface serving as a target for their related free radical reactions. Thus it inhibits copper ion dependent lipid peroxidation [40]. Therefore, the levels of GSH and ALB may be important indicators of the adverse effects caused by PAH ingestion.

As seen from our data reduced ALB and GSH levels in human plasma as well as in erythrocytes after consumption of charcoal broiled beefburger (CBB) for 28 consecutive days. We think that PAH ingestion causes some depression on the antioxidant defense potential of erythrocytes and thus, cells cannot cope with oxidant stress incurred by ingested PAH. Our think was supported by the work of Frenkel [41] and others, it is evident that during metabolism of PAHs by rat hepatic microsomes, substantial amounts of $\mathrm{O}_{2}^{-}$and catalase-inhibitable $\mathrm{H}_{2} \mathrm{O}_{2}$ are generated. The less carcinogenic PAHs, benzo(e)pyrene and anthracene, also induce ROS formation by rat liver microsomes but in lower amount. In addition, ROS can be formed during redox cycle of PAH quinones, as was shown to be the case for benzo(a)pyrene quinones in the presence of NADH dehydrogenase [42].

On the other side, the decreasing in ALB and GSH was contrary with increasing in serum aminotransferase enzyme activities GOT and GPT as well as ALP. Aminotransferases are normally intracellular enzymes. Thus, the presence of elevated levels of aminotransferase in the plasma indicates damage to cells rich in these enzymes. These enzymes are elevated in nearly all liver diseases, but are particularly high in conditions that the causes extensive cell necrosis, such as severe viral hepatitis and prolongated circulatory collapse. Serial enzyme measurements are often useful in determining the course of liver damage $[43,44]$. Also, aminotransferases may be elevated in nonhepatic disease, such as myocardial infraction and muscle disorders; however, these disorders can usually be distinguished clinically from liver disease [39]. AP is one of a number of cholestatic enzymes 
which are elevated in serum during cholestasis from either intrahepatic or extrahepatic bile ductular/duct obstructions [43]. The present data supporting many previous studies indicated that all of the enzymes activity GOT and GPT are represents excellent markers of liver damage caused by exposure to toxic substances including PAH [45-47].

In the correlation analysis, significant relations were found between analysis parameters. Intra correlation's between serum activities of liver functions of the periods (Table 4). Also, non-enzymatic antioxidant exhibited positive correlation's among the periods including serum and erythrocytes GSH. This means that GSH in serum and erythrocytes have a complementary role. Also, some important differences were however found in different periods in related to serum enzymes activity and nonenzymatic antioxidants (Table 6). For example, the relations between GOT and ALB, GSH-S, GSH-E; GPT and GSH-E; AP and GSH-E were positive in before CCB consumption period. All of these relations were disappeared during $\mathrm{CCB}$ consumption period and new negative relations between ALB and GOT, GPT; ALP and GSH-S were appeared. Also, there are no relations at all found in period of after CCB consumption. In the inter correlation analysis carried out between blood parameters of the subjects before and during CBB consumption, positive correlation were found for all studied parameters. But in during and after CBB consumption negative relations were found for GPT and ALP. All of these results showed that charcoal meat consumption caused important changes in the relation between serum enzymes activity and liver function.

\section{Conclusion}

PAH ingestion causes reduction in the non-enzymatic antioxidant defense potential of serum and erythrocytes and leads to oxidant stress due to both this reductions in antioxidant capacity and ROS formation as the consequence of PAHs metabolism. As a result of these metabolic events, ROS formation reactions are accelerated and some important changes occur in serum enzyme activities detecting the liver functions. Increase human awareness of PAH levels in grilled meat that is mainly depend on the method of cooking. Further study will be needed to assess and train nurses about the sources of PAH contamination of foodstuffs in order to maintain normal level of liver enzymes in human.

\section{Acknowledgements}

This study was financially supported by the Research Fund, Post-Graduate Studies and Research Sector, Minoufiya University, Shebin El-Kom, Egypt. The authors wish to acknowledge the contributions and dedication of Prof. Nazem S., Mansoura University, for assistance in statistical analysis. Also, the authors are grateful to all the subjects who participated in the study.

\section{REFERENCES}

[1] J. M, Van Maanen, E. J. Moonen, et al., "Formation of Aromatic DNA Adducts in White Blood Cells in Relation to Urinary Excretion of 1-Hydroxypyrene during Consumption of Grilled Meat," Carcinogenesis, Vol. 15, No. 10, 1994, pp. 2263-2268. doi:10.1093/carcin/15.10.2263

[2] R. Sinha and N. Rothman, "Role of Well-Done, Grilled Red Meat, Heterocyclic Amines (HCAs) in the Etiology of Human Cancer," Cancer Letters, Vol. 143, No. 2, 1999, pp. 189-194. doi:10.1016/S0304-3835(99)00123-8

[3] S. Y. Chung, R. R. Yettella, J. S. Kim, K. Kwon, et al., "Effects of Grilling and Roasting on the Levels of Polycyclic Aromatic Hydrocarbons in Beef and Pork," Food Chemistry, Vol. 129, No. 4, 2011, pp. 1420-1426.

doi:10.1016/j.foodchem.2011.05.092

[4] A. Farhadian, S. Jinap, F. Abas, et al., "Determination of Polycyclic Aromatic Hydrocarbons in Grilled Meat," Food Control, Vol. 21, No. 5, 2010, pp. 606-610. doi:10.1016/j.foodcont.2009.09.002

[5] E. Matos and A. Brandani, "Review on Meat Consumption and Cancer in South America," Mutation Research, Vol. 506-507, 2002, pp. 243-249. doi:10.1016/S0027-5107(02)00171-9

[6] R. G. Harvey, "Polycyclic Hydrocarbons and Carcinogenesis," ACS Symposium Series 283, American Chemical Society, Washington DC, 1985. doi:10.1021/bk-1985-0283

[7] E. W. Hawkins, W. W. Walker, R. M. Overstreet, et al., "Carcinogenic Effects of Some Polycyclic Aromatic Hydrocarbons on the Japanese Medaka and Guppy in Waterborne Exposures," The Science of the Total Environment, Vol. 94, No. 1-2, 1990, pp. 155-167. doi:10.1016/0048-9697(90)90370-A

[8] Y. A. Elhassaneen, "Biochemical and Technological Studies on Pollution of Fish with Pesticides and Polycyclic Aromatic Hydrocarbons," Ph.D. Thesis, Mansoura University, Mansoura, 1996.

[9] J. M. Sontag, "Carcinogensis in Industry and the Environment," Marcel Dekker Ltd., New York, 1981.

[10] D. H. Kang, N. Rothman, M. C. Poirier, et al., "Interindividual Differences in the Concentration of 1-Hydroxypyrene-Ghucuronide in Urine and Polycyclic Aromatic Hydrocarbon-DNA Adducts in Peripheral White Blood Cells after Charbroiled Beef Consumption," Carcinogenesis, Vol. 16, No. 5, 1995, pp. 1079-1085. doi:10.1093/carcin/16.5.1079

[11] Y. A. Elhassaneen and L. M. Tawfik, "The Presence of Some Carcinogens in Human Foods Distributed in Egyptian Local Markets," Research Bulletin, Vol. 8, 1998, pp. 15-30.

[12] J. P. Butler, G. P. Post and P. J. Lioy, et al., “Assessment 
of Carcinogenic Risk from Personal Exposure to Benzo(a)pyrene in the Total Human Environmental Exposure Study (THEES)," Journal of the Air \& Waste Management Association, Vol. 43, 1993, pp. 970-977.

[13] D. H. Phillips, "Polycyclic Aromatic Hydrocarbons in the Diet," Mutation Research, Vol. 443, No. 1-2, 1999, pp. 139-147. doi:10.1016/S1383-5742(99)00016-2

[14] P. Simko, "Determination of Polycyclic Aromatic Hydrocarbons in Smoked Meat Products and Smoke Flavoring Food Additives," Journal of Chromatography B, Vol. 770, No. 1-2, 2002, pp. 3-18. doi:10.1016/S0378-4347(01)00438-8

[15] World Health Organization (WHO), "WHO Guidelines for Drinking Water Quality, Recommendations," No. 130, WHO, Geneva, 1984.

[16] J. I. Gray and D. I. Morton, "Some Toxic Compounds Produced in Food by Cooking and Processing: A Review," International Journal of Food Sciences, Vol. 35, No. 1, 1981, pp. 5-23.

[17] G. O. Emerole, A. O. Uwaifo, M. Thabrew, et al., "The Presence of Aflatoxin and Some Polycyclic Aromatic Hydrocarbons in Human Foods," Cancer Letters, Vol. 15, No. 2, 1984, pp. 123-129. doi:10.1016/0304-3835(82)90041-6

[18] W. Lijinsky, "The Formation and Occurence of Polynuclear Aromatichydrocarbons Associated with Food," $\mathrm{Mu}$ tation Research/Genetic Toxicology, Vol. 259, No. 3-4, 1991, pp. 251-261. doi:10.1016/0165-1218(91)90121-2

[19] R. Barra, C. Castillo and J. P. Torres, "Polycyclic Aromatic Hydrocarbons in the South American Environment," Reviews of Environmental Contamination and Toxicology, Vol. 191, 2007, pp. 1-22. doi:10.1007/978-0-387-69163-3_1

[20] D. H. Kang, "Metabolic of Polycyclic Aromatic Hydrocarbons in Human Urine as Potential Biomarkers of Exposure," Ph.D. Thesis, Johns Hopkins School of Hygiene and Public Health, Baltimore, 1994.

[21] C. J. Kennedy, K. A. Gill and P. J. Walsh, "In Vitro Metabolism of Benzo(a)pyrene in the Blood of the Gulf Toadfish, Opsanus beta," Marine Environmental Research, Vol 31, No. 1, 1991, pp. 37-53. doi:10.1016/0141-1136(91)90004-R

[22] H.-C. Wu, Q. Wang, L. W. Wang, et al., "Polycyclic Aromatic Hydrocarbon- and Aflatoxin-Albumin Adducts, Hepatitis B Virus Infection and Hepatocellular Carcinoma in Taiwan," Cancer Letters, Vol. 252, No. 1, 2007, pp. 104-114. doi:10.1016/j.canlet.2006.12.010

[23] A.O.A.C., "Official Methods of the Association of Official Analytical Chemists," 16th Edition, Association of Official Analytical Chemists, Arlington, 1995.

[24] Y. A. Elhassaneen and L. M. Tawfik, "Cooking Oil Fumes Used in Some Egyptian Food Preparation as Sources of Toxic and Carcinogenic Substances," Fayoum Journal of Agricultural Research and Development, Vol. 15, 2001, pp. 66-79.

[25] E. A. Stroev and V. G. Akarova, "Laboratory Manual in Biochemistry," MIR Publishing, Moscow, 1989.
[26] P. J. Hissin and R. A. Hift, "Fluorometric Method for Determination of Oxidized and Reduced Glutatione in Tissue," Analytical Biochemistry, Vol. 47, 1976, pp. 214 266.

[27] O. H. Lowry, N. J. Rosebrough and R. J. Randal, "Protein Measurement with the Folin Phenol Reagent," The Journal of Biological Chemistry, Vol. 193, 1951, pp. 265-275.

[28] B. K. Larsson, G. P. Sahllerg, A. T. Eriksson, et al., "Polycyclic Aromatic Hsdrocarbons in Grilled Food," Journal of Agricultural and Food Chemistry, Vol. 31, No. 4, 1983, pp. 867-873. doi:10.1021/jf00118a049

[29] S. B. Baksi and J. M. Frazier, "Isolated Fish Hepatocytes Model Systems for Toxicology Research," Aquatic Toxicology, Vol. 16, No. 4, 1990, pp. 229-256. doi:10.1016/0166-445X(90)90039-R

[30] R. Lorentzen and P. Ts'o, "Benzo(a)pyrenedione/Benzo(a)pyrenediol Oxidation/Reduction Couples and the Generation of Reactive Reduced Molecular Oxygen," Biochemistry, Vol. 16, No. 7, 1977, pp. 1467-1476. doi: $10.1021 / \mathrm{bi00626a035}$

[31] A. M. Fulton, S. E. Loveless and G. H. Heppner, "Mutagenic Activity of Tumor Associated Macrophages in Salmonella Typhimurium Strains TA98 and TA100," Cancer Research, Vol. 44, 1984, pp. 4308-4311.

[32] A. W. Hsie, L. Resio, S. Katz, et al., "Evidence for Reactive Oxygen Species Inducing Mutations in Mammalian Cells," Proceedings of the National Academy of Sciences of the United States of America, Vol. 83, No. 24, 1986, pp. 9616-9620. doi:10.1073/pnas.83.24.9616

[33] K. Frenkel, "Carcinogen-Mediated Oxidant Formation and Oxidative DNA Damage," Pharmacology \& Therapeutics, Vol. 53, 1992, pp. 127-166.

[34] B. N. Ames, "Endogenous Oxidative DNA Damage, Aging, and Cancer," Free Radical Research, Vol. 7, No. 3-6, 1989, pp. 121-128. doi:10.3109/10715768909087933

[35] C. G. Fraga, P. A. Motchnik, M. K. Shigenaga, et al., "Ascorbic Acid Protects against Endogenous Oxidative DNA Damage in Human Sperm," Proceedings of the National Academy of Sciences of the United States of America, Vol. 88, No. 24, 1991, pp. 1-4.

[36] J. M. Carney, P. E. Starke-Reed and C. N. Oliver, "Reversal of Age-Related Increase in Brain Protein Oxidation, Decrease in Enzyme Activity, and Loss in Temporal and Spatial Memory by Chronic Administration of the Spin-Trapping Compound N-Tert-bytyl-a-phenylnitrone," Proceedings of the $\mathrm{Na}$ tional Academy of Sciences of the United States of America, Vol. 88, No. 9, 1991, pp. 3633- 3636.

[37] doi:k0.1073/pnas.8\&.83633. Antioxidants," Proceedings of the Society for Experimental Biology and Medicine. Society for Experimental Biology and Medicine, Vol. 200, No. 2,

[38] R.92: Ronzt8, 254 Encyclopedia of Nutrition and Good Health," Facts on File, Inc., New York, 1997.

[39] C. P. Champe and A. R. Harvey, "Biochemistry," 2nd Edition, JB Lippincott Company, Philadelphia, 1994. 
[40] J. M. Gutteridge and S. Wilkins, "Copper Salt-Dependant, Hydroxyl Radical Formation Damage to Proteins Acting as Antioxidant," Biochimica et Biophysica Acta (BBA), Vol. 759, No. 1-2, 1983, pp. 38-41. doi:10.1016/0304-4165(83)90186-1

[41] K. Frenkel, "The Role of Active Oxygen Species in Biological Damage and the Effect of Some Chemopreventive Agents," In: W. Troll and A. R. Kennedy, Eds., Protease Inhibitors as Cancer Chemopreventive Agents, Plenum Publishing Corp., New York, 1992.

[42] S. A. Lesko and R. J. Lorentzen, "Benzo(a)pyrene, Dione-Benzo(a)pyrene, Diol Oxidation-Reduction Couples; Involvement in DNA Damage, Cellular-Toxicity and Carcinogenesis," Journal of Toxicology and Environmental Health, Vol. 16, No. 5, 1985, pp. 679-691.

[43] Goij. 19:108f/15287398509530778 istry of Domestic Animals," 4th Edition, Academic Press, Inc., San Diego,
1989.

[44] F. A. Abd El-Aziz, "Study of Some Biochemical Markers in Some Malignant Disease," Ph.D. Thesis, Mansoura University, Mansoura, 1990.

[45] Y. A. Elhassaneen, "Toxicological and Biochemical Effects of Polycyclic Aromatic Hydrocarbon Compounds Produced in Fish by Cooking and Processing," Proceeding of the 6th Arabic Conference on Food Science and Technology, Egyptian Society of Food Science and Technology, Cairo, 16-18 March 1999, pp. 249-270.

[46] A. M. Attar, "The Influence of Dietary Grapeseed Oil on DMBA-Induced Liver Enzymes Disturbance in the Frog, Rana ridibunda," Pakistan Journal of Nutrition, Vol. 3, No. 5, 2004, pp. 304-309. doi:10.3923/pjn.2004.304.309

[47] K. Broeg, W. Kaiser, S. Bahns, et al., "The Liver of Wrasse-Morphology and Function as a Mirror of Point Source Chemical Impact," Marine Environmental Research, Vol. 66, No. 1, 2008, pp. 191-192. doi:10.1016/j.marenvres.2008.02.056 